\title{
Formulation and characterization of bilayer films based on Brea gum and Pectin
}

\author{
Formulação e caracterização de filmes de dupla camada baseados em \\ goma Brea e Pectina
}

\author{
Aníbal Marcelo Slavutsky ${ }^{1,2 *}$, Jimena Elizabeth Gamboni' ${ }^{1}$, María Alejandra Bertuzzi ${ }^{1}$ \\ 'Universidad Nacional de Salta (UNSA), Instituto de Investigaciones para la Industria Química (INIQUI-CONICET), Salta/SA - Argentina \\ ¿Universidad Nacional de Salta (UNSA), Facultad de Ingeniería, Salta/SA - Argentina
}

\section{*Corresponding Author}

Aníbal Marcelo Slavutsky, Universidad Nacional de Salta (UNSA), Instituto de Investigaciones para la Industria Química (INIQUI-CONICET), Av. Bolivia 5150, A4408TVY, Salta/SA - Argentina, e-mail: amslavutsky@gmail.com

Cite as: Formulation and characterization of bilayer films based on Brea gum and Pectin. Braz. J. Food Technol., v. 21, e2017213, 2018.

Received: Nov. 07, 2017; Accepted: July 12, 2018

\section{Abstract}

The formulation of bilayer films is a strategy aimed at combining the advantages and properties of different film-forming materials. Bilayer films based on pectin and brea gum were formulated and their functional properties studied and compared with those presented by single layer films of each component. The micrographs and surface properties confirmed that the bilayer films can maintain their identity and prevent delamination. The mechanical properties of the films depended on the characteristics of the polymers and their interactions, and the bilayer films showed prevalence of the brea gum properties. The brea gum films showed high solubility that influenced the bilayer film solubility. The water vapour permeability of the bilayer films was dependent on the material that was exposed to the side where desorption occurred. The bilayer films presented lower water vapour permeability than the brea gum films but higher than that of pectin films of similar thicknesses. The differential properties of each layer of bilayer films make them potentially interesting for controlled drug release.

Keywords: Bilayer film; Surface properties; Work of adhesion; Work of cohesion; Spreading coefficient; Sorption isotherms; Mechanical properties; Water vapour permeability.

\section{Resumo}

Formulação de filmes bicamada é uma estratégia para combinar vantagens e propriedades de diferentes materiais formadores de filmes. Filmes de bicamada à base de pectina e goma brea foram formulados, e suas propriedades funcionais foram estudadas e comparadas com aquelas apresentadas por filmes de camada única de cada componente. As micrografias e as propriedades da superfície confirmaram que os filmes bicamada podem manter sua identidade e prevenir a delaminação. As propriedades mecânicas dos filmes dependeram das características e interações do polímero. Verificou-se que os filmes bicamada mostraram prevalência das propriedades da goma brea. Os filmes de goma brea apresentaram alta solubilidade, a qual influenciou a solubilidade do filme bicamada. A permeabilidade ao vapor de água dos filmes bicamada dependeu do material que constituiu o lado em que ocorreu a dessorção. Os filmes de bicamada apresentaram permeabilidade ao vapor de água menor que os filmes de goma brea e maior que os filmes de pectina, de espessuras semelhantes. As propriedades diferenciais de cada camada dos filmes de bicamada os tornam potencialmente interessantes para a liberação controlada de drogas.

Palavras-chave: Filmes bicamada; Propriedades da superfície; Energia de aderência; Energia de coesão; Coeficiente de espalhamento; Isoterma de sorção; Propriedades mecânicas; Permeabilidade. 


\section{Introduction}

The biopolymers obtained from vegetables, animals and microorganisms have considerable potential for the replacement of conventional polymers in food packaging. They possess selective gas transfer properties $\left(\mathrm{CO}_{2} / \mathrm{O}_{2}\right)$, but due to their hydrophilic character they have poor water vapour barrier properties, and their mechanical and barrier properties are affected by the water content, limiting their application in food packaging (VIEIRA et al., 2011).

Pectin is an edible polysaccharide mainly extracted from citrus peel. It is a structural heteropolysaccharide containing acid and neutral residues. Its solubility in water depends on the degree of substitution of the carboxyl groups on the D-galacturonic acid units. Pectin is used in the food and pharmaceutical industries as a gelling agent (NISHIJIMA et al., 2009) but its application as a film matrix is limited by its high water solubility.

Brea gum (BG) is the exudate obtained from the Brea tree (Cercidium praecox). Cerezo et al. (1969) and Castel et al. (2016) described the chemical structure of BG as an acid heteropolysaccharide that also contains between $4 \%$ and $10 \%$ of proteins that form a polysaccharide-protein complex. The toxicological analyses of BG indicated that it is not toxic for human ingestion (VON MÜLLER et al., 2009) and it was recently included as a food additive in the Argentine Food Code (ARGENTINA, 2014). BG presents physicochemical properties similar to those of gum Arabic, and can therefore be used as a substitute for gum Arabic in food applications (BERTUZZI et al., 2012). Bertuzzi and Slavutsky (2013) determined the formulation and characterization of edible films based on BG. The films were transparent and presented high mechanical resistance and elevated water solubility and water vapour permeability, and the incorporation of montmorillonite (MMT) nanoparticles improved the barrier and mechanical properties (SLAVUTSKY et al., 2014; SLAVUTSKY; BERTUZZI, 2015). In addition, Spotti et al. (2016) formulated emulsified $\mathrm{BG} /$ beeswax films and observed that an increase in the beeswax content produced a decrease in water vapour permeability, deteriorating its mechanical properties.

The formulation of bilayer films is a strategy aimed at combining the advantages and properties of different materials. Rivero et al. (2009) and Chen et al. (2010) formulated bilayer films from gelatine/chitosan and starch/decolorized hsian-tsao leaf gum, respectively. The results indicated that the bilayer films presented better properties than the simple layer films. The composition of BG and pectin suggests a favourable chemical interaction between both compounds, indicating adequate compatibility for the formulation of bilayer films.

The aims of this work were to formulate bilayer films based on pectin and BG and to study the improvements in the functional properties in relation to those corresponding to the simple layer films.

\section{Materials and methods}

\subsection{Materials}

BG was provided by a native community group from Tartagal, Salta, Argentina. The BG exudate was collected from brea tree (Cercidium praecox) in the form of small drops or tears. The purification process and characteristics of BG powder were described by Bertuzzi et al. (2012). Low methoxil Pectin (LM-104-AS) was provided by Gelfix S.A. Glycerol (Mallinckrodt, USA) was added as plasticizer. All salts used in sorption isotherms determinations were provided by Aldrich (USA).

\subsection{Film preparation}

\subsection{Preparation of $B G$ films}

The film-forming solution was prepared by dissolving $20 \% \mathrm{w} / \mathrm{v} \mathrm{BG}$ in water and adding glycerol at a concentration of $10 \% \mathrm{w} / \mathrm{w}$ of the $\mathrm{BG}$. The resulting solution was incubated for 60 minutes in an ultrasonic bath at $60^{\circ} \mathrm{C}$ to eliminate any retained air bubbles and then poured over polystyrene plates. Films of two different thicknesses were prepared by controlling the amount of solution poured ( $5 \mathrm{~mL}$ : sample BG1; $10 \mathrm{~mL}$ : sample BG2). The samples were then placed in an air-circulating oven at $35^{\circ} \mathrm{C}$ and $53 \% \mathrm{RH}$ for 15 hours, then removed from the oven and the films peeled off. The films were stored at $25^{\circ} \mathrm{C}$ and $53 \% \mathrm{RH}$ before characterization.

\subsubsection{Preparation of pectin films}

The film-forming solution was prepared by dissolving $3 \% \mathrm{w} / \mathrm{v}$ pectin in water and adding glycerol at a concentration of $10 \% \mathrm{w} / \mathrm{w}$ of the pectin. The solutions were mechanically stirred for 3 hours and the resulting solution incubated for 60 minutes in an ultrasonic bath at $60^{\circ} \mathrm{C}$ to eliminate any retained air bubbles and then poured onto polystyrene plates. Films of two different thicknesses were prepared by controlling the volume of solution poured over the plates (18 mL: sample P1; $35 \mathrm{~mL}$ : sample P2). They were then dried and stored at $25^{\circ} \mathrm{C}$ and $53 \% \mathrm{RH}$ before characterization.

\subsubsection{Preparation of bilayer films}

Before the pectin films were removed from the polystyrene plates (sample P1), a defined volume of BG solution ( $5 \mathrm{~mL}$ ) was poured over each pectin film. The samples were then dried and stored at $25{ }^{\circ} \mathrm{C}$ and $53 \% \mathrm{RH}$ before characterization.

\subsection{Scanning Electron Microscopy (SEM)}

The cross-section and surface of the film samples were examined by SEM using a JEOL JSM 6480 LV scanning microscope (Japan). The samples were previously 
stored in a controlled relative humidity ambient for a week $(53 \% \mathrm{RH})$, cryofractured by immersion in liquid nitrogen and then stored at $25^{\circ} \mathrm{C}$ over silica gel. The film samples were finally supported on aluminium stubs, coated with gold plasma, and observed using an accelerating voltage of $15 \mathrm{kV}$.

\subsubsection{Surface properties of the simple layer films and bilayer films.}

The surface properties of the different films were analysed by way of contact angle measurements, analysing both the polar and dispersive components. The contact angle $(\theta)$ of a liquid drop on a solid surface is defined by the mechanical equilibrium of the drop under the action of three interfacial tensions: solid-vapour $\left(\gamma_{\mathrm{sv}}\right)$, solid-liquid $\left(\gamma_{S L}\right)$, and liquid-vapour $\left(\gamma_{L V}\right)$. When a liquid of known surface tension is in static equilibrium with a solid surface, the relationship between the surface tensions is:

$$
\gamma_{\mathrm{S}}=\gamma_{\mathrm{SL}}+\gamma_{\mathrm{LV}} \cos \theta
$$

where $\gamma_{S}$ is the surface tension of the solid substrate. According to the Zisman theory, in systems having a surface tension below $100 \mathrm{mN} \mathrm{m}^{-1}$ (low-energy surfaces), the contact angle formed by a drop of liquid on a solid surface will be a linear function of the surface tension of the liquid, $\gamma_{\mathrm{LV}}$ (where phase $\mathrm{V}$ is air saturated with the vapour of the liquid, L) (ZISMAN, 1964). The critical surface tension $\left(\gamma_{c}\right)$ was estimated by extrapolation from the Zisman plots. The critical surface tension is defined as:

$$
\gamma_{c}=\lim _{\theta \rightarrow 0} \gamma_{L V}
$$

The thermodynamic theory of adhesion indicates that when the dispersive $\left(\gamma_{L}{ }^{d}\right)$ and polar $\left(\gamma_{L}{ }^{p}\right)$ components of the surface tension of a pure liquid are known, and the contact angle $(\Theta)$ between the solid surface and the liquid can be determined, the interaction can be described in terms of the reversible work of adhesion, Wa, as:

$$
W a=W_{a}^{d}+W_{a}^{p} \Leftrightarrow W a=2 \cdot\left(\sqrt{\gamma_{s}^{d} \cdot \gamma_{L}^{d}}+\sqrt{\gamma_{s}^{p} \cdot \gamma_{L}^{p}}\right)
$$

Where $W_{a}{ }^{d}$ and $W_{a}{ }^{p}$ are dispersive London forces and polar forces (acid-base interactions, for example) respectively and $\gamma_{S}{ }^{\mathrm{p}}$ and $\gamma_{S}{ }^{\mathrm{d}}$ are the polar and dispersive contributions of the solid surface under study. Replacing in Equation 2 and rearranging the yields:

$$
\frac{1+\cos \theta}{2} \cdot \frac{\gamma_{L}}{\sqrt{\gamma_{L}^{\mathrm{d}}}}=\sqrt{\gamma_{S}^{\mathrm{p}}} \cdot \sqrt{\frac{\gamma_{L}^{\mathrm{p}}}{\gamma_{L}^{\mathrm{d}}}}+\sqrt{\gamma_{S}^{\mathrm{d}}}
$$

Equation 4 represents a straight line. The contact angle measured with different fluids was used to determine the independent variable $\sqrt{\frac{\gamma_{\mathrm{L}}^{\mathrm{p}}}{\gamma_{\mathrm{L}}^{\mathrm{d}}}}$ and the dependent variable, $\frac{1+\cos \theta}{2} \cdot \frac{\gamma_{L}}{\sqrt{\gamma_{L}^{d}}}$ and the polar and dispersive components of the solid were obtained from these values (CLINT; WICKS, 2001; BALDAN, 2012).

The contact angle $(\theta)$ was measured using the sessile drop method at room temperature with a goniometer (Standard Goniometer with DROP image standard, model 200-00, Ramé-Hart Instrument Co., Succasunna, USA). The contact angles of the following pure liquids were measured: ethylene glycol, glycerol, formamide and ultra-pure water. The surface tension and the dispersive and polar components of these liquids were obtained from the bibliography as follows: $48.3,29.3$ and $19.00 \mathrm{mN} \mathrm{m}^{-1}, 63.4,37.1$ and $26.3 \mathrm{mN} \mathrm{m}^{-1}$, 58.2, 32.2 and $26.00 \mathrm{mN} \mathrm{m}^{-1}$ and $72.10,19.90$ and $52.20 \mathrm{mN} \mathrm{m}^{-1}$, respectively (GHANBARZADEH et al., 2007; BALDAN, 2012). Five samples of each film formulation were tested and all tests were carried out at time zero in order to eliminate the anomalous behaviour of swelling.

\subsubsection{Work of adhesion (Wa), work of cohesion (Wc) and spreading coefficient (Ws)}

The work of adhesion, work of cohesion and spreading coefficient between the pectin film and BG solution used to formulate the bilayer films were determined from the contact angle measurements. The affinity between the phases increases as the forces of attraction between them (bond strengths) become greater than the forces of attraction between the molecules of the same phase (cohesive forces). The work of adhesion is defined as the energy per unit area required to separate two phases and is equal and opposite to the energy per unit area released when forming the interface. The work of cohesion for a pure substance is the energy per unit area required to produce two new surfaces containing the same molecules. The contact angle of a liquid on a surface is related to the work of adhesion, and can be calculated from the following equation:

$\mathrm{Wa}=\gamma_{\mathrm{LV}} \cdot(1+\cos \theta)$

The work of cohesion is defined by:

$\mathrm{Wc}=2 \cdot \gamma_{\mathrm{LV}}$

The equilibrium spreading coefficient can be calculated from Equation (6) and can only be negative or zero.

$W \mathbf{S}=W c-W a=\gamma_{S V}-\gamma_{L V}-\gamma_{S L}$

The surface tension of a $20 \% \mathrm{w} / \mathrm{v}$ BG solution was determined by Bertuzzi et al. (2012) as having a value of $49.13 \pm 3.25 \mathrm{mN} \mathrm{m}^{-1}$. Five samples of each film formulation were tested and all tests were carried out at time zero in order to eliminate the anomalous behaviour of swelling. 


\subsection{Mechanical properties}

The mechanical properties of the films were measured using a Brookfield texturometer (Massachusetts, USA) according to ASTM D882 (ASTM, 2010a) with some modifications. Elongation at break (\% $\mathrm{E})$, tensile strength $(\mathrm{T})$ and Young's modulus $(\mathrm{Y})$ were calculated according to ASTM D882 (ASTM, 2010a). The samples were conditioned for 48 hours at $25^{\circ} \mathrm{C}$ and $53 \% \mathrm{RH}$ before testing. Each type of film was tested five times. The distance between the clamps (gap) was $50.0 \mathrm{~mm}$ and the sample width $25 \mathrm{~mm}$.

\subsection{Film solubility in water (S)}

The water solubility of the films was measured as a percentage of the dry matter of the film, left soaking in water for 24 hours. The initial dry matter of each film was obtained after drying film specimens in desiccators containing $\mathrm{P}_{2} \mathrm{O}_{5}$ for a week. Samples of approximately $1000 \mathrm{mg}$ were weighed and immersed in $50 \mathrm{~mL}$ distilled water at $35^{\circ} \mathrm{C}$, sealed and shaken. Films that did not dissolve in the water were separated by centrifugation (Gelek G142, Argentina) at $3000 \mathrm{~g}$ and dried at $50{ }^{\circ} \mathrm{C}$ to determine the remaining dry matter. The tests were carried out in triplicate and the solubility calculated as follows:

$S=\left(\frac{\text { Initialdry weight }- \text { Finaldry weight }}{\text { Initialdry weight }}\right) \times 100$

\subsection{Moisture sorption isotherms}

The moisture sorption isotherms were obtained at $35^{\circ} \mathrm{C}$ using a gravimetric method. The water activities $\left(a_{w}\right)$ of the ambients ( 0.1 to 0.9 ) were obtained using the different salts recommended by the European project COST-90 (SPIESS; WOLF, 1983). Each analysis was carried out in quadruplicate at each $\mathrm{a}_{\mathrm{w}}$. A complete description of the methodology was previously described in Bertuzzi et al. (2007b).

The sorption data were fitted to the BET model as described by Equation 9:

$$
\mathrm{w}_{\mathrm{e}}=\frac{\mathrm{w}_{0} \cdot \mathrm{C} \cdot \mathrm{a}_{\mathrm{w}}}{\left(1-\mathrm{a}_{\mathrm{w}}\right) \cdot\left(1+(\mathrm{C}-1) \cdot \mathrm{a}_{\mathrm{w}}\right)}
$$

where $w_{e}$ is the equilibrium moisture content ( $g$ water/100 $g$ dry film), $\mathrm{w}_{0}$ is the monolayer content ( $\mathrm{g}$ water $/ 100 \mathrm{~g}$ dry film), and $\mathrm{C}$ is a temperature dependent adsorption constant.

\subsection{Water vapour permeability}

The apparatus and methodology described in ASTM E96 were used to measure film permeability (ASTM, 2010b). The samples were stored at 53\% RH for 72 hours before the analyses. The permeability was measured at $25{ }^{\circ} \mathrm{C}$ and each analysis was carried out in triplicate.
The films were sealed in cups containing distilled water (100\% RH). The test cups were placed in a desiccator cabinet maintained at constant temperature containing a saturated $\mathrm{Mg}\left(\mathrm{NO}_{3}\right)_{2}$ salt solution that provides an $\mathrm{RH}$ of $53 \%$. A description of the methodology used was given by Slavutsky et al. (2012). The thickness value was the mean value of nine measurements obtained using an analogical thickness gauge (Digimess, Argentine). The water vapour transmission rate (WVTR) was calculated from the slope $(G)$ of the linear regression line of weight loss versus time (Equation 10), and the water vapour permeability $(P)$ was calculated according to Equation 11:

$$
\begin{aligned}
& \text { WVTR }=\frac{G}{A} \\
& P=\text { cte. } \frac{\text { WVTR.I }}{\left(p_{w i}-p_{w 0}\right)}
\end{aligned}
$$

where I is the film thickness; A the exposed film area, $\mathrm{p}_{\text {wo }}$ is the partial pressure of the water vapour at the film surface outside the cup, $p_{w i}$ is the partial pressure of the water vapour of the distilled water or saturated solution inside the cup, and cte is a constant that satisfies unit conversions.

\subsection{Statistical analysis}

The statistics applied to the results obtained from the completely randomized design were carried out using the analysis of variance (ANOVA) procedure and Graph Pad Prism 5.01 software. Tukey's multiple range test $(p \leq 0.05)$ was used to detect differences between the mean values of the film properties.

\section{Results}

The films formed by a single layer of just one polymer and the bilayer films were formulated using $B G$ and pectin as the polymeric matrixes. The pectin films were colourless and transparent and the BG films were transparent, but presented an amber colour. The bilayer films were made by pouring BG solutions onto a pectin film. The inverse process was not possible due to the high level of swelling and water solubility of the BG films.

\subsection{Scanning electron microscopy}

Figure 1 shows the cross sections of the bilayer films. Both layers of the bilayer films presented dense and homogenous structures. Moreover, the interfaces between the layers of both films were slightly delimited, which was probably due to the high affinity existing between the two materials. Strong adhesion between the layers is important to avoid delamination, which can affect the mechanical and barrier properties of bilayer films. 
Formulation and characterization of bilayer films based on Brea gum and Pectin

Slavutsky, A. M. et al.

\subsection{Surface properties of the bilayer films}

Table 1 shows the contact angle measurements of different pure liquids on the film samples. The sessile drop technique, using pure water as the testing liquid, is a useful tool to determine the hydrophobic or hydrophilic characteristics of a surface. Low contact angles indicate that the solid surface presents hydrophilic characteristics, while high contact angles reveal hydrophobic properties. The results indicated that the pectin films had less affinity for water than the BG films. Similar results were reported by Sriamornsak et al. (2008) and by Bertuzzi and Slavutsky (2013). Kowalonek et al. (2010) reported that apolar interactions are developed when a higher contact angle is formed, indicating less wettability of the film surface. The hydrophilic groups of the pectin are preferably oriented towards the inside of the film, and for this reason the surface becomes slightly more hydrophobic, whereas the BG films show the opposite behaviour. No differences were observed between the contact angles of samples with different thicknesses (data not shown). In addition, the contact angles of each side of the bilayer films showed no significant differences from those obtained by single layer films, confirming the strong cohesion and independence of each layer.

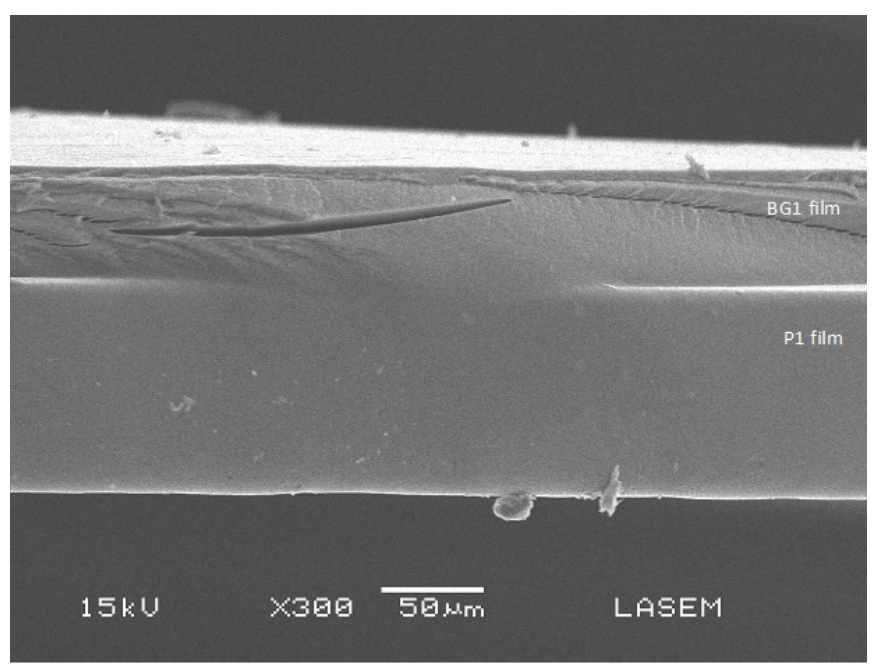

Figure 1. SEM images of bilayer films.
Moreover, the Zisman theory (ZISMAN, 1964) indicates that the critical surface free energy $\left(\gamma_{c}\right)$ can be used to determine the wettability of a material. A high value for $\gamma c$ indicates that the solution wets the surface and spreads properly over it. Based on this theory, complete wetting can be expected when the critical tension of a solid has a contact angle of zero. Table 2 shows the values for $\gamma_{c}$ obtained for the different film samples. Both film surfaces (pectins and BG) behaved like low-energy surfaces (values below $100 \mathrm{mN} \mathrm{m}^{-1}$ ). According to Rulon and Robert (1993), these materials interact with liquids mainly through dispersive forces and hence the results indicated that the pectin films were less hydrophilic than the BG films. Basiak et al. (2016) reported a critical surface tension for starch based films of $36 \mathrm{mN} \mathrm{m}{ }^{-1}$, while Ghanbarzadeh et al. (2007) found a value of $20.40 \mathrm{mN} \mathrm{m}^{-1}$ for the critical surface tension of zein based films.

The polar and dispersive components and surface energy of the films were calculated using the Thermodynamic theory of adhesion (Table 2). The polar component predominated on the BG films, indicating a highly hydrophilic nature, but to the contrary, the dispersive component was the dominant component on the pectin samples, consistent with a less hydrophilic nature. Kowalonek et al. (2010) obtained similar results for pectin films.

Adhesion between the BG solution and the pectin films was studied in order to ensure the correct formation of the bilayer films (Table 3). The $\gamma_{c}$ is a measurement of the free surface energy of the solid, which demarcates those liquids which can spread on the solid surface as a thin continuous film $\left(\gamma_{L V}<\gamma_{C}\right)$, from those that cannot $\left(\gamma_{L V}>\gamma_{C}\right)$. The $\gamma_{c}$ of the pectin films (Table 2) was lower than the $\gamma_{L V}$ of the BG solution (Table 3), ensuring the identity of the BG layer over the pectin layer while the bilayer was being formed. The work of adhesion values indicated that strong adhesion existed between the pectin film and the $B G$ solution, guaranteeing the integrity of the bilayer. Moreover, the negative value of the Ws of the BG solution showed that it was possible to spread the solution over the surface of the pectin film. These results confirm the strong adhesion between the BG phase and the pectin film and guarantee good compatibility between the components

Table 1. Contact angle measurements of the film samples.

\begin{tabular}{ccccc} 
Sample & Water & Formamide & Ethylene glycol & Glycerol \\
BG & $58.53 \pm 2.48^{\mathrm{a}}$ & $52.34 \pm 1.01^{\mathrm{a}}$ & $24.40 \pm 0.52^{\mathrm{a}}$ & $67.86 \pm 2.58^{\mathrm{a}}$ \\
P & $78.26 \pm 4.91^{\mathrm{b}}$ & $63.73 \pm 2.10^{\mathrm{b}}$ & $39.51 \pm 2.90^{\mathrm{b}}$ & $76.66 \pm 2.95^{\mathrm{b}}$ \\
\hline
\end{tabular}

Similar letters show equality between the means at $p<0.05$. BG $=$ Brea gum; $P=$ Pectin.

Table 2. Dispersive components, polar components and surface energy of the film samples.

\begin{tabular}{ccccc} 
& $\gamma \mathbf{c}\left(\mathbf{m N ~ m}^{-1}\right)$ & $\gamma_{\mathbf{s}}{ }^{\mathbf{d}}\left(\mathbf{m N ~ m}^{-1}\right)$ & $\gamma_{\mathbf{s}}{ }^{\mathbf{p}}\left(\mathbf{m N ~ m}^{-1}\right)$ & $\gamma_{\mathbf{s L}}\left(\mathbf{m N ~ m}^{-1}\right)$ \\
BG & $38.38 \pm 2.02^{\mathrm{a}}$ & $14.83 \pm 2.72^{\mathrm{a}}$ & $23.83 \pm 3.35^{\mathrm{a}}$ & $38.66 \pm 1.08^{\mathrm{a}}$ \\
$\mathrm{P}$ & $36.59 \pm 2.29^{\mathrm{a}}$ & $21.24 \pm 5.86^{\mathrm{b}}$ & $10.09 \pm 5.86^{\mathrm{b}}$ & $31.32 \pm 1.04^{\mathrm{b}}$ \\
\hline
\end{tabular}

The same letters indicate equality between the means with $p<0.05$. BG = Brea gum; $P=$ Pectin. 
Formulation and characterization of bilayer films based on Brea gum and Pectin

Slavutsky, A. M. et al.

of the bilayer films, avoiding delamination. In addition, the results justify the good compatibility and continuity observed in the SEM images of the bilayer films.

\subsection{Mechanical properties}

Table 4 shows the results for the assay of tensile strength. The values for $\mathrm{T}$ and \% $\mathrm{E}$ of the single layer films (BG films and pectin films) increased with film thickness. According to Bertuzzi et al. (2007b), if the film matrix presents a homogenous structure, the T values will be independent of the thickness. Table 4 shows the mean thicknesses of the film samples (pectin films, BG films and bilayer films). Bertuzzi et al. (2007a) indicated that during the drying step of the suspension, the polymer matrix could be modified and their properties affected by the time available for chain inter-diffusion and arrangement. The possibility for the rearrangement of the molecules is related to the time available for this process, and hence to the time taken for the water to evaporate during film formation by the casting technique. Thicker films require longer drying times and provide more time for chain inter-diffusion and arrangement. The Young module presented similar values for all types of film, independent of film thickness. The results indicated that the BG films were brittle and rigid while the pectin films were more flexible.

Table 3. Thermodynamic surface properties of BG solution on Pectin films.

$\begin{array}{cr}\text { BG } \gamma_{\text {Lv }}\left(\mathbf{m N ~ m}^{-1}\right) & \mathbf{4 9 . 1 3} \pm \mathbf{3 . 2 5} \\ \Theta_{\text {BG/P }}\left({ }^{\circ}\right)^{\star} & 81.28 \pm 4.60 \\ W a\left(m N ~ m^{-1}\right) & 56.43 \pm 3.86 \\ W c\left(m N ~ m^{-1}\right) & 98.26 \pm 6.50 \\ W s\left(m N ~ m^{-1}\right) & -41.57 \pm 3.87\end{array}$

${ }^{*} \Theta=$ Contact angle formed between $B G$ solution and Pectin films. $B G=$ Brea gum. Wa $=$ work of adhesion; $W c=$ work of cohesion; Ws = spreading coefficient.
Laminated films usually present poor mechanical properties due to the phenomenon of delamination. However the bilayer films based on BG and pectin did not present delamination and showed a reinforced structure with higher $Y$ values than the pectin films. According to Rivero et al. (2009), bilayer films present similar mechanical properties to those obtained for the single layer films. This occurs when adhesion between the single layers used to formulate the bilayer films is strong, and the materials have similar mechanical properties, e.g. two polysaccharides or a polysaccharide and a protein. Conversely, Debeaufort and Quezada-Gallo (2000) reported that the mechanical properties of bilayer films only depend on the more fragile component of the matrix, due to the loss of integrity of the laminated material. They formed laminated films based on polysaccharides or proteins and lipids and lipids constitute the more fragile layer, which tends to delaminate. The pectin films showed more ductility and flexibility than the BG films. Considering the formulation, the bilayer films were formed by $62.5 \%$ of $B G$ and $37.5 \%$ of pectin (on a dry weight basis) and the results presented in Table 4 show that the mechanical properties of the bilayer films depended on the BG layer (BG1), the more brittle component present in greater proportions.

\subsection{Water solubility of the films and the moisture sorption isotherms}

The water solubility (S) of the films is an important property of these materials since it gives information about their possible applications and limitations. This characteristic depends on various parameters, such as, temperature, agitation and solute/solvent ratio. Table 5 shows the $S$ values of the different films. The BG films dissolved completely under the experimental conditions but the pectin films presented low solubility (19\%) and film

Table 4. Mechanical properties of the films.

\begin{tabular}{ccccc}
\hline & Tensile strength $(\mathbf{M P a})$ & \% Elongation at break & Young module $(\mathbf{M P a})$ & Thickness $(\mathbf{m}) \times \mathbf{1 0 ^ { - 0 }}$ \\
P1 & $22.88 \pm 1.77^{\mathrm{a}}$ & $21.63 \pm 2.31^{\mathrm{a}}$ & $231.31 \pm 34^{\mathrm{a}}$ & $8.21 \pm 0.12^{\mathrm{a}}$ \\
P2 & $22.20 \pm 1.31^{\mathrm{a}}$ & $20.55 \pm 1.37^{\mathrm{a}}$ & $243.02 \pm 23^{\mathrm{a}}$ & $18.03 \pm 0.53^{\mathrm{b}}$ \\
BG1 & $18.88 \pm 3.09^{\mathrm{b}}$ & $4.23 \pm 0.73^{\mathrm{b}}$ & $553.36 \pm 17.6^{\mathrm{b}}$ & $7.45 \pm 0.13^{\mathrm{a}}$ \\
BG2 & $23.77 \pm 1.89^{\mathrm{a}}$ & $7.17 \pm 0.69^{\mathrm{c}}$ & $534.31 \pm 34^{\mathrm{b}}$ & $17.63 \pm 0.18^{\mathrm{b}}$ \\
P1/BG1 & $19.93 \pm 1.10^{\mathrm{b}}$ & $4.66 \pm 0.47^{\mathrm{b}}$ & $475.69 \pm 12^{\mathrm{c}}$ & $17.37 \pm 0.35^{\mathrm{b}}$ \\
\hline
\end{tabular}

The same letters indicate equality between the means with $p<0.05 . B G=$ Brea gum; $P=$ Pectin.

Table 5. BET model parameters and film solubility in water.

\begin{tabular}{cccccc} 
& w & $\mathbf{C}$ & $\mathbf{R}^{2}$ & \% Error & $\mathbf{S}$ \\
P1 & $4.551^{\mathrm{a}}$ & $2.280^{\mathrm{a}}$ & 0.9662 & 2.982 & $18.77 \pm 0.27$ \\
P2 & $4.303^{\mathrm{a}}$ & $3.753^{\mathrm{a}}$ & 0.9783 & 2.238 & $18.83 \pm 0.31$ \\
BG1 & $8.806^{\mathrm{b}}$ & $0.431^{\mathrm{b}}$ & 0.9909 & 1.033 & -- \\
BG2 & $7.918^{\mathrm{b}}$ & $0.451^{\mathrm{b}}$ & 0.9910 & 0.945 & -- \\
$\mathrm{P} 1 / \mathrm{BG} 1$ & $6.152^{\mathrm{c}}$ & $0.989^{\mathrm{a}, \mathrm{b}}$ & 0.9939 & 1.644 & $50.98 \pm 1.70$ \\
\hline
\end{tabular}

The same letters indicate equality between the means with $p<0.05$. BG = Brea gum; $P=$ Pectin; $w=$ monolayer moisture content; $C=$ temperature dependent adsorption constant; $\mathrm{R}^{2}=$ Pearson correlation; $\mathrm{S}=$ solubility. 
Formulation and characterization of bilayer films based on Brea gum and Pectin

Slavutsky, A. M. et al.

solubility was independent of film thickness. The bilayer films showed dissolution of the BG layer, while the pectin layer maintained its integrity. This property could be used for applications involving controlled drug delivery, where the active component could be incorporated in the BG layer, and then liberated when this layer is dissolved in contact with hydrophilic solvents.

Figure 2 shows the moisture sorption data and the fitting of the BET model for the BG1, P1 and P1/BG1 films. The water content data for $a_{w}$ values exceeding 0.8 were not considered for the BG films due to their high hydrophilicity, dissolution and disintegration. The moisture contents of the samples increased with increase in the equilibrium relative humidity, following a Type II curve of the BET classification. The behaviour of these samples was characteristic of hydrophilic films and an exponential increase in water moisture content was observed above $a_{w}=0.5$. The moisture contents of the pectin and bilayer films were lower than those presented by the BG films when the value for $a_{w}$ rose above 0.7. According to Bertuzzi et al. (2007b) when hydrophilic films increase their water content, their structure is modified due to swelling of the polymeric chains and an increase in the degree of freedom of the water.

Table 5 shows the fit of the model parameters to the data (BET model). No significant differences were

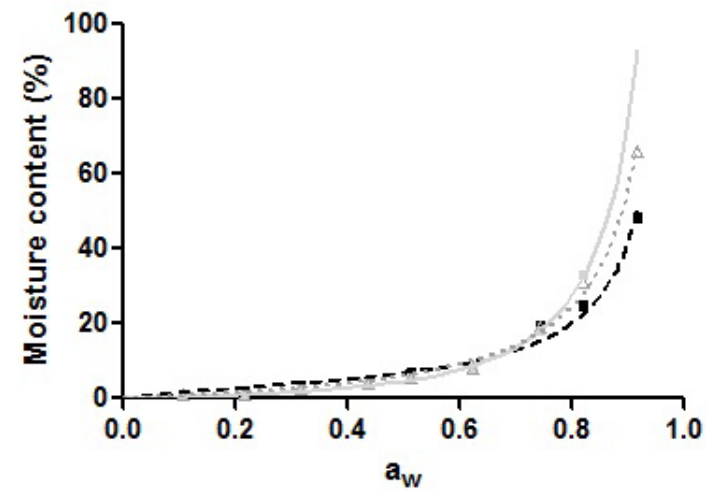

Figure 2. Moisture sorption isotherm data of pectin films ( $\mathbf{\square}), \mathrm{BG}$ films $(\bullet)$ and P1/BG1 films $(\Delta)$. BET model fitting (pectin - - BG __ and P1/BG1 ....). . BG: Brea gum. P: Pectin. BET: Brunauer, Emmett and Teller sorption ishoterm model. observed between the samples of each single layer film, indicating that the moisture sorption process was independent of film thickness. The pectin films presented lower monolayer values than the BG films, and the bilayer films gave intermediate values. The constant $C$ is related to the energy of the water-substrate interaction and the $C$ values corresponding to the BG films were lower than those presented by the pectin films, while the bilayer film showed intermediate values. These results indicate that the adsorption of water molecules is promoted by the more hydrophilic component. Similar behaviour was observed by Chen et al. (2010). These results are in agreement with those of the study of the surface properties of the films presented in section 3.2.

Due to the high capacity of the BG films to adsorb water molecules, they could act as sacrificed materials while the pectin film brings structure and mechanical resistance to the bilayer film. In addition, the pectin films could be dissolved under certain conditions, depending on the $\mathrm{pH}$ value and the presence of cation sequestrants or pectinolytic enzymes (colonic enzymes), giving the material differential dissolution conditions for each layer.

\subsection{Water vapour permeability}

Permeability and WVTR are important functional properties used to evaluate and compare the behaviours of different hydrophilic films. Permeation can be separated into three basic steps, the adsorption of water molecules onto the inner surface $\left(a_{w}=1\right)$, diffusion through the film matrix and desorption on the outer surface $\left(a_{w}=0.53\right)$. The diffusion process depends on the path taken by the water molecules, and thuson film thickness but to the contrary, adsorption and desorption are independent of film thickness. Samples of pectin and BG films with different thicknesses were tested and the data presented in Table 6 shows an increase in permeability of the BG films with increasing thickness, but a practically constant WVTR. The same trend was previously observed in high amylose starch based films by Bertuzzi et al. (2007b) and in sodium caseinate films and pullulan films by Kristo, Biliaderis and Zampraka (2007). In the case of the BG films, the rise in permeability was related to the increase in thickness since the WVTR remained practically constant.

Table 6. Water vapour permeability of the film samples.

\begin{tabular}{ccccc} 
Sample (in/out) ${ }^{*}$ & $\mathbf{a}_{\mathbf{w}}{ }^{\text {in }}$ & $\mathbf{a}_{\mathbf{w}}{ }^{\text {out }}$ & WVTR (g/day. $\mathbf{m}^{\mathbf{2})}$ & $\mathbf{P}(\mathbf{g} / \mathbf{m} . \mathbf{s} . \mathbf{P a}) \times \mathbf{1 0}^{-\mathbf{1 0}}$ \\
\hline P1 & 1.00 & 0.53 & $1431.63 \pm 22.61^{\mathrm{a}}$ & $9.23 \pm 0.34^{\mathrm{a}}$ \\
P2 & 1.00 & 0.53 & $662.85 \pm 69.19^{\mathrm{b}}$ & $9.44 \pm 0.23^{\mathrm{a}}$ \\
BG1 & 1.00 & 0.53 & $1179.24 \pm 53.85^{\mathrm{c}}$ & $6.94 \pm 0.25^{\mathrm{b}}$ \\
BG2 & 1.00 & 0.53 & $1134.92 \pm 46.80^{\mathrm{c}}$ & $15.87 \pm 0.27^{\mathrm{c}}$ \\
P1/BG1\# & 1.00 & 0.53 & $953.88 \pm 22.01^{\mathrm{d}}$ & $13.03 \pm 0.22^{\mathrm{d}}$ \\
BG1/P1\# & 1.00 & 0.53 & $742.64 \pm 36.60^{\mathrm{e}}$ & $10.51 \pm 0.34^{\mathrm{a}}$ \\
\hline
\end{tabular}

The same letters indicate equality between the means with $p<0.05 . a_{w}$ in $:$ water activity inside the cup; $a_{w}$ ut : water activity outside the cup; WVTR: water vapor transmission rate; P: permeability. " Location of each layer of bilayer films in the test cup. 
Formulation and characterization of bilayer films based on Brea gum and Pectin

Slavutsky, A. M. et al.

This could be explained by the control of the sorption and desorption steps in the permeation process.

To the contrary, the pectin films showed a decrease in WVTR with increasing thickness and constant permeability values, and thus the permeation process could be controlled by the diffusive step and the swelling effect caused by the water molecules in the film matrix (McHUGH et al., 1993).

Each face of the bilayer films was alternatively exposed to the inner side (high $a_{w}$ ) of the test cup in the water vapour permeability assays. It was observed that the WVTR and the permeability of the film with the pectin layer located on the inner side of the test cup were higher than those presented by the bilayer film when the BG layer was located on the inner side of the test cup. This indicates that the behaviour of the bilayer films depends on the face where the desorption process occurs. Thus higher WVTR and permeability were observed when desorption occurred from the BG layer, due to the greater solubility of this material and the greater freedom of the water molecules for vaporization.

The permeability of the bilayer films was compared with those of the BG2 and P2 film samples, since there were not significant differences between the thicknesses of all these films. The water vapour permeability of both bilayer films was significantly lower than that of the BG2 films, and higher than that of the P2 films.

\section{Conclusions}

Pectin and brea gum were used to formulate bilayer films. The favourable work of cohesion and of adhesion ensured adequate spreading of the brea gum solution on the pectin film, and strong adhesion between the two materials when the bilayer films were formed. This guaranteed the integrity of the composite material and prevented delamination. The mechanical properties of the bilayer films were comparable to the values presented by the single layer films with similar thicknesses. Film solubility was independent of film thickness. Due to the high solubility of brea gum, the solubility of the bilayer film depended on the brea gum layer. Water vapour permeability and water vapour transmission rate were dependent on the face of the bilayer film exposed to the side where desorption occurred. Bilayer films presented values for water vapour permeability and transmission rate that were lower than those of brea gum films and higher than those of pectin films with similar thicknesses. Each layer of the bilayer films showed differential properties such as water solubility and surface hydrophilicity, making them potentially interesting for controlled drug release.

\section{Acknowledgements}

The financial support provided by the Consejo de Investigación de la Universidad Nacional de Salta (CIUNSa-Project №2260), Agencia Nacional Científica y
Tecnológica (PICT 2015-1275) and CONICET (PIP 2015 $\left.N^{\circ} 11220150100348\right)$ are gratefully acknowledged. The authors wish to thank Ing. José Bravo and Lic. Verónica Colodro for their collaboration.

\section{References}

ASTM INTERNATIONAL - ASTM. D882: standard test methods for tensile properties of thin plastic sheeting. Philadelphia, 2010a.

ASTM INTERNATIONAL - ASTM. E96: standard test methods for water vapor transmission of materials. Philadelphia, 2010b.

ARGENTINA. Administración Nacional de Medicamentos, Alimentos y Tecnología Médica. Capítulo XVIII. Artículo 1398. Apartado 72.1 Goma brea. Código Alimentario Argentino, Buenos Aires, 2014. Available at: <http://www.anmat.gov.ar/alimentos/ normativas_alimentos_caa.asp >. Accessed on: 07 nov. 2017.

BALDAN, A. Adhesion phenomena in bonded joints. International Journal of Adhesion and Adhesives, v. 38, p. 95-116, 2012. http://dx.doi.org/10.1016/j.ijadhadh.2012.04.007.

BASIAK, E.; DEBEAUFORT, F.; LENART, A. Effect of oil lamination between plasticized starch layers on film properties. Food Chemistry, v. 195, p. 56-63, 2016. http://dx.doi.org/10.1016/j. foodchem.2015.04.098. PMid:26575712.

BERTUZZI, M. A.; ARMADA, M.; GOtTIFREDI, J. C. Physicochemical characterization of starch based films. Journal of Food Engineering, v. 82, n. 1, p. 17-25, 2007a. http://dx.doi. org/10.1016/j.jfoodeng.2006.12.016.

BERTUZZI, M. A.; VIDAURRE, E. F. C.; ARMADA, M.; GOTTIFREDI, J. C. Water vapor permeability of edible starch based films. Journal of Food Engineering, v. 80, n. 3, p. 972-978, $2007 \mathrm{~b}$. http://dx.doi.org/10.1016/j.jfoodeng.2006.07.016.

BERTUZZI, M. A.; SLAVUTSKY, A. M.; ARMADA, M. Physicochemical characterisation of the hydrocolloid from Brea tree (Cercidium praecox). International Journal of Food Science \& Technology, v. 47, n. 4, p. 768-775, 2012. http://dx.doi.org/10.1111/j.13652621.2011.02907.x.

BERTUZZI, M. A.; SLAVUTSKY, A. M. Formulation and characterization of film based on brea gum. Journal Food Science Engineering, v. 3, p. 113-122, 2013.

CASTEL, V.; ZIVANOVIC, S.; JURAT-FUENTES, J. L.; SANTIAGO, L. G.; RuBiolo, A. C.; CARRARA, C. R.; HARTE, F. M. Chromatographic fractionation and molecular mass characterization of Cercidium praecox (Brea) gum. Journal of the Science of Food and Agriculture, v. 96, n. 13, p. 4345-4350, 2016. http:// dx.doi.org/10.1002/jsfa.7642. PMid:26801963.

CEREZO, A. S.; STACEY, M.; WEBBER, M. J. Some structural studies of Brea gum (an exudate from Cercidium australe jonhst.). Carbohydrate Research, v. 9, n. 4, p. 505-517, 1969. http:// dx.doi.org/10.1016/S0008-6215(00)80035-X. 
Formulation and characterization of bilayer films based on Brea gum and Pectin

Slavutsky, A. M. et al.

CHEN, C.; KUO, W.; LAI, L. Food hydrocolloids water barrier and physical properties of starch/decolorized hsian-tsao leaf gum films: impact of surfactant lamination. Food Hydrocolloids, v. 24, n. 2-3, p. 200-207, 2010. http://dx.doi.org/10.1016/j. foodhyd.2009.09.006.

CLINT, J. H.; WICKS, A. C. Adhesion under water: surface energy considerations. International Journal of Adhesion and Adhesives, v. 21, n. 4, p. 267-273, 2001. http://dx.doi. org/10.1016/S0143-7496(00)00029-4.

DEBEAUFORT, F.; QUEZADA-GALLO, J. Lipid hydrophobicity and physical state effects on the properties of bilayer edible films. Journal of Membrane Science, v. 180, n. 1, p. 47-55, 2000. http://dx.doi.org/10.1016/S0376-7388(00)00532-9.

GHANBARZADEH, B.; MUSAVI, M.; OROMIEHIE, A. R.; REZAYI, K.; RAD, E. R.; MILANI, J. Effect of plasticizing sugars on water vapor permeability, surface energy and microstructure properties of zein films. Lebensmittel-Wissenschaft + Technologie, v. 40, n. 7, p. 1191-1197, 2007. http://dx.doi.org/10.1016/j.Iwt.2006.07.008.

KOWALONEK, J.; KACZMAREK, H.; D BROWSKA, A. Air plasma or UV-irradiation applied to surface modification of pectin/poly(vinyl alcohol) blends. Applied Surface Science, v. 257, n. 1, p. 325-331, 2010. http://dx.doi.org/10.1016/j.apsusc.2010.07.005.

KRISTO, E.; BILIADERIS, C. G.; ZAMPRAKA, A. Water vapour barrier and tensile properties of composite caseinate-pullulan films: biopolymer composition effects and impact of beeswax lamination. Food Chemistry, v. 101, n. 2, p. 753-764, 2007. http://dx.doi.org/10.1016/j.foodchem.2006.02.030.

MCHUGH, T. H.; AVENA-BUSTILLOS, R.; KROCHTA, J. M. Hydrophilic edible films: modified procedure for water vapor permeability and explanation of thickness effects. Journal of Food Science, v. 58, n. 4, p. 899-903, 1993. http://dx.doi. org/10.1111/j.1365-2621.1993.tb09387.x.

NISHIJIMA, T.; IWAI, K.; SAITO, Y.; TAKIDA, Y.; MATSUE, H. J. Chronic ingestion of apple pectin can enhance the absorption of quercetin. Journal of Agricultural and Food Chemistry, v. 57 , n. 6, p. 2583-2587, 2009. http://dx.doi.org/10.1021/jf803547h. PMid:19292474.

RIVERO, S.; GARCíA, M. A.; PINOTTI, A. Composite and bi-layer films based on gelatin and chitosan. Journal of Food Engineering, v. 90, n. 4, p. 531-539, 2009. http://dx.doi. org/10.1016/j.jfoodeng.2008.07.021.
RULON, J.; ROBERT, H. Wetting of low-energy surfaces. In: BERG, J. C. (Ed.). Wettability. Washington: Marcel, 1993. chap. 1, p. 4-73.

SLAVUTSKY, A. M.; BERTUZZI, M. A.; ARMADA, M. Water barrier properties of starch-clay nanocomposite films. Brazilian Journal of Food Technology, v. 15, n. 3, p. 208-218, 2012. http://dx. doi. org/10.1590/S1981-67232012005000014.

SLAVUTSKY, A. M.; BERTUZZI, M. A.; ARMADA, M.; GARCÍA, M. G.; $\mathrm{OCHOA}, \mathrm{N}$. A. Preparation and characterization of montmorillonite/ brea gum nanocomposites films. Food Hydrocolloids, v. 35, p. 270-278, 2014. http://dx.doi.org/10.1016/j.foodhyd.2013.06.008.

SLAVUTSKY, A. M.; BERTUZZI, M. A. Thermodynamic study of water sorption and water barrier properties of nanocomposite films based on brea gum. Applied Clay Science, v. 108, p. 144-148, 2015. http://dx.doi.org/10.1016/j.clay.2015.02.011.

SPIESS, W. E. L.; WOLF, W. F. The results of the COST 90 project on water activity. In: JOWITT, R. (Ed.). Physical properties of foods. London: Applied Science Publishers, 1983.

SPOTTI, M. L.; CECCHINI, J. P.; SPOTTI, M. J.; CARRARA, C. R. Brea Gum (from Cercidium praecox) as a structural support for emulsion-based edible films. LWT - Food Science and Technology, v. 68, p. 127-134, 2016.

SRIAMORNSAK, P.; WATTANAKORN, N.; NUNTHANID, J.; PUTTIPIPATKHACHORN, S. Mucoadhesion of pectin as evidence by wettability and chain interpenetration. Carbohydrate Polymers, v. 74 , n. 3, p. 458-467, 2008. http://dx.doi.org/10.1016/j. carbpol.2008.03.022.

VIEIRA, M.; SILVA, M. A.; SANTOS, L. O.; BEPPU, M. M. Naturalbased plasticizers and biopolymer films: a review. European Polymer Journal, v. 47, n. 3, p. 254-263, 2011. http://dx.doi. org/10.1016/j.eurpolymj.2010.12.011.

VON MÜLLER, A. R.; LÓPEZ, C. B.; EYNARD, A. R.; GUZMÁN, C. A. Subchronic toxicological evaluation of brea gum (Parkinsonia preacox) as a food additive in BALB/c mice. Drug and chemical toxicology, v. 32, n. 4, p. 307-311, 2009. http://dx.doi. org/10.1080/01480540902976903. PMid:19793021.

ZISMAN, W. A. Contact angle wettability and adhesion. In: FOWKES, F. M. (Ed.). Advances in chemistry series. Washington: American Chemical Society, 1964. chap. 1, p. 1-51. 